\title{
DISKUSI MENGENAI PERAN HUMAS DALAM KOMUNIKASI INTERNAL PADA PERUSAHAAN
}

\author{
Yugih Setyanto $^{1}$, Paula T. Anggarina ${ }^{2}$ \\ ${ }^{1}$ Fakultas Komunikasi, Universitas Tarumanagara, Jakarta \\ Email: yugihs@ fikom.untar.ac.id \\ ${ }^{2}$ Fakultas Ekonomi, Universitas Tarumanagara, Jakarta \\ Email: paula.anggarina@gmail.com
}

\begin{abstract}
ABSTRAK
Komunikasi internal menjadi salah satu hal penting yang menunjang kinerja perusahaan. Melalui komunikasi internal, terjalin alur pesan di dalam perusahaan. Kelancaran komunikasi ini menjadi indikator baik tidaknya manajemen dijalankan. Banyak masalah yang timbul dikarenakan terhambatnya komunikasi yang terjadi di perusahaan. Komunikasi internal menjadi hal penting dalam menunjang manajemen perusahaan. Humas dalam fungsi manajemen menjadi pendukung dalam membangun komunikasi tersebut. Sampai sejauh ini belum semua perusahaan memahami pentingnya humas dalam membangun komunikasi internal. PT. Pupuk Kalimantan Timur merupakan salah satu BUMN yang berkantor pusat di Bontang, Kalimantan Timur. Selain itu, perusahaan ini juga memiliki kantor perwakilan yang berada di Jakarta. Kantor ini memiliki peran yang vital sebagai jembatan komunikasi antara manajemen di pusat dan stakeholder di Jakarta. Kegiatan diskusi memberi masukan kepada perusahaan mengenai pandangan akademis mengenai komunikasi internal. Sehingga melalui fungsi kehumasan dapat membantu manajemen di Kantor PT Pupuk Kaltim perwakilan Jakarta.
\end{abstract}

Kata kunci: Komunikasi, Komunikasi Internal, Humas.

\section{PENDAHULUAN}

Komponen utama yang sangat menentukan keberlanjutan sebuah perusahaan adalah sumber daya manusia. Sebagai aset utama yang dimiliki perusahaan, sumber daya manusia sampai dengan karyawan menjadi inti dari beroperasinya sebuah perusahaan.

Interaksi yang terjadi di dalam perusahaan sangat dipengaruhi oleh latar belakang karyawan baik dari sisi budaya maupun sosial. Interaksi menjadi kompleks bila karyawan berasal dari latar belakang budaya yang heterogen. Perusahaan harus mampu mengakomodasi perbedaan ini. Karyawan menggunakan komunikasi sebagai "kendaraan" dalam berinteraksi sehingga bisa dikatakan komunikasi dalam organisasi adalah urat nadi proses manajemen dalam perusahaan.

Komunikasi organisasi identik dengan komunikasi internal. Romli (2014:6).memasukkan komunikasi internal sebagai salah satu dimensi yang ada dalam kehidupan organisasi. Disampaikannya bahwa Komunikasi internal organisasi adalah proses penyampaian pesan antara anggota-anggota organisasi yang terjadi untuk kepentingan organisasi, seperti komunikasi antara pimpinan dan bawahan, antara sesama bawahan, dsb.

Tanpa komunikasi internal yang baik tentu sulit mencapai tujuan perusahaan yang diinginkan. Banyak contoh permasalahan yang dihadapi perusahaan akibat dari kurang baiknya komunikasi. Demo yang dilakukan buruh adalah salah satunya. Terhambatnya alur komunikasi dalam perusahaan menjadi salah satu penyebab terjadinya ketidak harmonisan.

PT. Pupuk Kalimantan Timur (Pupuk Kaltim) adalah salah satu BUMN terbesar di Indonesia yang belokasi di Bontang, Kalimantan Timur. Namun lokasi kegiatan pengabdian 
masyarakat dilakukan di kantor perwakilan Jakarta. Sebagai sebuah organsiasi bisnis yang besar masalah komunikasi internal menjadi sangat penting. Terlebih perusahaan ini (PT. Pupuk Kalimantan Timur) memiliki kantor tersebar di mana-mana. Walau berkantor pusat di Bontang, Kalimantan Timur., namun peran kantor Jakarta sangat strategis dan penting

Kantor pusat sangat berkepentingan akan keberadaan para stafnya di Jakarta untuk menopang manajemen yang ada. Kebijakan yang diambil di kantor pusat juga harus dapat diterima oleh para staf di Jakarta. Namun demikian, ada pula kebijakan yang tidak sepenuhnya dapat diterapkan di kantor Jakarta karena dipengaruhi faktor kebijakan eksternal misalnya kebijakan Pemda terkait upah minimum regional (UMR) yang berbeda di setiap daerah.

Selain itu, pejabat yang menjadi manager di kantor Jakarta juga harus dapat mengkomunikasikan berbagai kebijakan pusat kepada para staf yang ada. Permasalahan komunikasi yang terjadi di Kantor Pupuk Kaltim Perwakilan Jakarta, serta bagaimana mensinergikan komunikasi kantor pusat menjadi topik dalam makalah ini.

Melalui Program pengabdian masyarakat ini akan mencoba menyatukan sudut pandang akademis dan praktis sehingga menghasilkan masukan yang konstruktif bagi perusahaan dan dunia akademis.

\section{METODE PELAKSANAAN}

Penulisan artikel ini merupakan hasil diskusi yang dilakukan dengan pimpinan dan staf Kantor Pupuk Kaltim perwakilan Jakarta dalam rangka program Pengabdian Masyarakat pada 5 April 2018. Sebelumnya sudah dilakukan pengamatan terhadap permasalahan yang dihadapi mitra. Dalam dialog tatap muka itu terjadi diskusi untuk saling memberi penjelasan dari berbagai sudut pandang.

Kegiatan ini dilatarbelakangi adanya kepentingan moral perguruan tinggi dalam memberikan perspektif akademik dalam permasalahan yang dihadapi masyarakat. Selain itu masukan yang didapat dari diskusi ini juga bermanfaat bagi akademisi untuk menambah pengetahuan praktik yang seseungguhnya terjadi di masyarakat.

Sementara itu perusahaan juga memerlukan masukan dari sisi akademik untuk menjadi evaluasi pengembangan manajemennya. Selain diskusi juga, dilakukan obeservasi serta studi literatur untuk memperdalam analisis di tulisan ini. Referensi untuk literatur yang digunakan terutama terkait komunikasi dan humas.

\section{GAMBARAN PELAKSANAAN KEGIATAN}

Pelaksanaan kegiatan berupa diskusi yang melibatkan staf Kantor Pupuk Kaltim Perwakilan Jakarta. Upaya ini dilakukan untuk memberi pemahaman dan mendapatkan masukan mengenai aspek-aspek humas yang patut untuk diketahui kedua pihak. Kegiatan ini menjadi ajang bertukar pikiran sehingga mendapat solusi dari pandangan akademis sekaligus mendapat masukan mengenai kondisi terkini dalam kehumasan khususnya terkait mengelola komunikasi internal di perusahaan. Materi diskusi merupakan bentuk partisipasi aktif dalam penerapan bidang keilmuan kepada masyarakat. 
Pelaksanaan kegiatan PkM bertempat di Kantor Pupuk Kaltim Perwakilan Jakarta. Bentuk kegiatan berupa diskusi mengenai peran humas dalam komunikasi internal. Komunikasi internal menjadi bagian tak terpisahkan dalam manajemen sebuah perusahaan. Kondisi komunikasi yang ada menjadi gambaran akan hubungan antara pimpinan dan bawahan serta sebaliknya. Kondisi ini dapat mempengaruhi kinerja perusahaan.

Sebagai mitra diskusi adalah Manajer Kantor Pupuk Kaltim Perwakilan Jakarta Wirza Eka dan staf. Karena humas Pupuk Kaltim berada di kantor pusat yang berlokasi di Bontang Kalimantan Timur maka fungsi humas di Jakarta dilakukan oleh Manajer Kantor perwakilan.

Dalam kegiatan ini Tim Untar menyampaikan berbagai hal terkait bagaimana humas menjalankan fungsi komunikasi dalam perusahaan. Pada presentasi disampaikan gambaran umum bahwa humas merupakan bagian dari manajemen dalam mencapai tujuan perusahaan.

Menurut Morissan (2008:8) mengutip Dominick, Humas mencakup hal-hal sebagai berikut:

1. Public Relations memiliki kaitan erat dengan opini public.

Pada satu sisi, praktisi public relations berupaya untuk mempengaruhi public agar memberikan opini yang positif bagi organisasi atau perusahaan, namun pada sisi lain public relations harus berupaya mengumpulkan informasi dari khalayak, menginterpretasikan informasi itu dan melaporkannya kepada manajemen jika informasi itu memiliki pengaruh terhadap keputusan manajemen.

\section{Public Relations memiliki kaitan erat dengan komunikasi.}

Praktisi public relations bertanggung jawab menjelaskan tindakan perusahaan kepada khalayak yang berkepentingan dengan organisasi atau perusahaan. Khalayak yang berkepentingan akan selalu tertarik dengan apa saja yang dilakukan perusahaan. Praktisi public relations harus memberikan perhatian terhadap pikiran dan perasaan khalayak terhadap organisasi. PR harus menjadi saluran arus bolak-balik antara organisasi dan khalayaknya. Organisasi pada dasarnya berhubungan dengan berbagai macam khalayak.

3. Public Relations merupakan fungsi manajemen.

Public relations berfungsi membantu manajemen dalam menetapkan tujuan yang hendak dicapai serta menyesuaikan diri terhadap lingkungan yang berubah. PR juga harus secara rutin memberikan saran kepada manajemen. PR harus memiliki kegiatan yang terencana dengan baik. Bagian PR harus mampu mengorganisir dan mengarahkan dirinya untuk mencapai suatu tujuan tertentu.

Dari pendapat di atas pada poin ketiga dapat menjadi referensi bahwa humas merupakan fungsu manajemen pada perusahaan. Seorang humas menjadi bagian dari penentu arah kebijakan yang dibuat pimpinan perusahaan.

Sedangkan peran humas menurut Center-Cutlip-Bloom (2009:46), yaitu:

\section{Teknisi Komunikasi}

Kebanyakan praktisi masuk ke bidang ini sebagai teknisi komunikasi. Deskripsi kerja dalam lowongan pekerjaan biasanya menyebutkan keahlian komunikasi dan jurnalistik sebagai 
syarat. Teknisi komunikasi disewa untuk menulis dan mengedit newsletter karyawan, menulis news release dan feature, mengembangkan isi Web, dan menangani kontak media.

\section{Expert Presciber}

Ketika para praktisi mengambil peran sebagai pakar/ahli, orang lain akan menganggap mereka sebagai otoritas dalam persoalan PR dan solusinya. Praktisi yang beroperasi sebagai praktisi pakar bertugas mendefinisikan problem, mengembangkan program, dan bertanggung jawab penuh atas implementasinya. Peran ini menarik perhatian praktisi karena menjalani peran ini akan membuat orang dilihat sebagai pihak yang punya otoritas ketika ada sesuatu hal yang harus dibereskan atau pihak yang punya otoritas untuk menentukan bagaimana cara mengerjakan segala sesuatu.

\section{Fasilitator Komunikasi}

Peran fasilitator komunikasi bagi seorang praktisi adalah sebagai pendengar yang peka dan broker (perantara) komunikasi. Fasilitator komunikasi bertindak sebagai perantara (liaison), interpreter, dan 25 mediator antara organisasi dan publiknya. Mereka menjaga komunikasi dua arah dan memfasilitasi percakapan dengan menyingkirkan rintangan dalam hubungan dan menjaga agar saluran komunikasi tetap terbuka. Tujuannya adalah memberi informasi yang dibutuhkan oleh baik itu manajemen maupun public untuk membuat keputusan demi kepentingan bersama. Praktisi yang berperan sebagai fasilitator komunikasi ini bertindak sebagai sumber infomasi dan agen kontak resmi antara organisasi dan publik.

\section{Fasilitator Pemecah Masalah.}

Ketika praktisi melakukan peran fasilitator pemecah masalah, mereka berkolaborasi dengan manajer lain untuk mendefinisikan dan memecahkan masalah. Mereka menjadi bagian dari tim perencanaan strategis. Praktisi pemecah masalah membantu manajer lain dan organisasi untuk mengaplikasikan PR dalam proses manajemen bertahap yang juga dipakai untuk memecahkan problem organisasional lainnya.

Bila mengacu dari peran humas yang disampaikan di atas, Manajer di kantor Jakarta berperan sebagai fasilitator komunikasi. Manajer perwakilan menjadi mediator antara pimpinan di kantor pusat dengan para stakeholder perusahaan yang ada di Jakarta.

Terkait dengan komunikasi internal, Humas membantu manajemen sebagai boundary spanning yaitu praktisi humas berusaha mengkomunikasikan berbagai kepentingan dan kebijakan manajemen kepada khalayak namun juga berupaya menjembatani kepentingan khalayak agar dapat diterima manajemen. (Prayudi 2012:53).

Dari diskusi yang terjadi terdapat beberapa hal yang mengemuka diantaranya bahwa humas Pupuk Kaltim sesungguhnya sudah berupa unit kerja tersendiri. Namun lokasinya ada di Bontang Kalimantan Timur tempat dimana kantor pusat perusahaan berada. Oleh sebab untuk kantor perwakilan Jakarta fungsi humasnya dilakukan oleh manajer kantor perwakilan.

Menurut Wirza Eka, walau kantor pusat ada di Bontang justru membuat kantor perwkilan ini menjadi penting. Lokasinya yang berada di ibukota membuat banyak kegiatan-kegiatan manajemen yang penting dilakukan di kantor perwakilan ini. Terlebih para manajer puncak perusahaan juga lebih sering bekerja di kantor ini. Hal ini disebabkan banyak interaksi menyangkut bisnis perusahaan yang harus dilakukan di Jakarta. 
Jakarta adalah ibukota dimana pusat pemerintahan berada. Artinya, salah satu stakeholder perusahaan yaitu pemerintah berada di Jakarta. Pupuk Kaltim adalah BUMN yang tak bisa lepas dari kebijakan pemerintah sebagai pemegang saham terbesar perusahaan. Peran seorang Kepala kantor dapat menjadi boundary spanning antara pemerintah sebagai regulator dengan manajemen di kantor pusat. Itulah mengapa walau Kantor perwakilan yang tingkatannya berada di bawah kantor pusat justru memegang peran penting dalam layanan operasional manajemen.

Berbicara mengenai Kantor Perwakilan Jakarta (KPJ), orang akan berasumsi bahwa KPJ menitik beratkan pada services sebagai pokok tugas yang utama. Memang tidak bisa dipungkiri hal tersebut memang benar adanya,namun di samping itu, KPJ memiliki tugas pokok dan fungsinya, antara lain:

1. Kehumasan : Departemen yang berfungsi mempertahankan dan melindungi reputasi perusahaan, mengevaluasi sikap dan opini public terhadap perusahaan, formulasi dan implementasi serta mengembangkan hubunga positif antara perusahaan dengan departemen yang terkait dengan perusahaan dan masyarakat di lingkungan perusahaan.

2. Sekretariat : Secara umum, sebagian besar masyarakat menganggap bahwa sekretariat berfungsi menyiapkan surat-menyurat, menerima tamu, dan mengagendakan surat intern maupun ekteren.

Disamping tugas tersebut, sekretariat juga harus bisa memberikan masukkan kepada Direksi dan Dekom untuk mematuhi ketentuan perundang-undangan dalam pengambilan kebijakan yang berhubungan langsung dengan tata persuratan perusahaan.

3. General Affair: Bertugas sebagai pendukung kegiatan operasional perusahaan melalui pengadaan barang dan jasa yang dibutuhkan. Dalam melakukan tugasnya, general affair banyak melakukan koordinasi dengan departemen keuangan untuk melakukan koordinasi mengenai rencana anggaran biaya pengadaan barang dan jasa.

4. Keuangan : Departemen ini mengemban segala kegiatan atau aktivitas perusahaan yang berhubungan dengan bagaimana cara memperoleh pendanaan modal kerja, menggunakan atau mengalokasikan dana dan mengelola asset yang dimiliki untuk mencapai tujuan utama perusahaan.

5. Personalia : Departemen yang berfungsi sebagai mengelolanya SDM pada hal-hal yang terkait administratif dan mengatur hubungan industrial antara perusahaan dengan perusahaannya. Selain itu, bertanggungjawab terhadap employee, database, payroll dan pembayaran benefit lainnya (termasuk pinjaman karyawan, absensi, pencatatan cuti tahunan, filling dokumen dan rekruitmen.

Sehingga bisa dikatakan, bahwa Kantor Perwakilan Jakarta merupakan miniatur dari Kantor Pusat PT Pupuk Kaltim.

Sesuai dengan uraian diatas dan image yang terbangun untuk Kantor Perwakilan Jakarta yaitu services maka kantor perwakilan Jakarta memiliki Visi Service Excellent, yang artinya dalam melaksanakan tugas hendaknya dapat meminimalisir complain dari berbagai pihak. 
Selain itu, KPJ juga mengevaluasi karyawannya dengan upaya pendidikan serta pembinaan agar kinerjanya lebih optimal, dengan cara memberikan pelatihan terhadap kebutuhan karyawan guna menunjang pekerjaan.

Melalui diskusi ini diketahui hal-hal yang menjadi masalah komunikasi yang dihadapi perusahaan dan tim memberikan masukan dari pendekatan akademis.

\section{KESIMPULAN DAN SARAN}

1. Staf Kantor Pupuk Kaltim Perwakilan Jakarta mendapatkan deskripsi akademis mengenai fungsi humas dalam menunjang manajemen di perusahaan.

2. Menjadi fondasi kerja sama yang bersifat konsultatif antara perusahaan dan perguruan tinggi khususnya dalam manajemen komunikasi kehumasan. Kantor Pupuk Kaltim Perwakilan Jakarta dapat menjadikan Tim PKM Untar sebagai mitra dialog untuk mendapat masukan mengenai masalah komunikasi dihadapi. Sementara itu Tim PKM Untar bisa mendapatkan pengetahuan praktis yang dapat menjadi materi pengajaran di kelas.

3. Sebagai bahan evaluasi kedepan, kegiatan serupa dapat dilakukan dengan berbagai perusahaan dengan menyesuaikan materi menurut kondisi perusahaan yang menjadi mitra. Misalnya untuk perusahaan besar dan kompleks dengan variasi masalah komunikasi yang berbeda pula atau Usaha Mikro, Kecil, dan Menengah (UMKM) dengan berbagai keterbasan yang ada. Hal ini juga bermanfaat untuk membangun hubungan yang kontrukstif antara dunia kampus dan korporasi serta masyarakat secara nyata. Selain itu menambah pengalaman dan pengetahuan yang menunjang pembelajaran sebagai dosen.

\section{Ucapan Terima Kasih}

Terima kasih kepada Universitas Tarumanagara melalui Direktorat Penelitian dan Pengabdian Masyarakat atas bantuannya serta jajaran manajemen Kantor Pupuk Kaltim Perwakilan Jakarta yang telah memberi kesempatan terlaksananya kegiatan ini.

\section{DAFTAR PUSTAKA}

Cutlip, Scott M, Allen H. Center, \& Glen M. Broom. (2009). Effective Public Relations Edisi Kesembilan. Jakarta: Prenada Media Group

Morissan. (2008). Manajemen Public Relations: Strategi Menjadi Humas Profesional. Jakarta: Kencana Perdana Media Group

Romli, Prof. Dr.Khomsahrial (2014), Komunikasi Organsiasi Lengkap, Grasindo, Jakarta

Sunarto (2012) Humas Pemerintah dan Komunikasi Persuasif, Alfabeta Bandung,

Prayudi (2012), Public Relations Stratejik, Komunikasi UPN Press 